\title{
AZ ÉRTÉKESÍTÉS DIGITÁLIS ÁTALAKULÁSA - AZ EGYÉNI ÉS SZERVEZETI TECHNOLÓGIAELFOGADÁST MEGHATÁROZÓ TÉNYEZŐK EMPIRIKUS ELEMZÉSE
}

\author{
DIGITAL TRANSFORMATION IN SALES - EMPIRICAL ANALYSIS OF \\ FACTORS DETERMINING INDIVIDUAL AND ORGANIZATIONAL \\ TECHNOLOGY ACCEPTANCE
}

\begin{abstract}
Jelen tanulmány az értékesítés digitális átalakulását befolyásoló tényezők feltárására vállalkozik. A kutatás során a szerzők felvázolnak egy elméleti modellt, amely egyaránt támaszkodik a Technológiaelfogadás Modelljére (TAM), a Technológiai Felkészültség Indexére (TRI), valamint az értékesítési tevékenységek és eszközök szakirodalmára. Az elméleti modell megalkotásához az empíria egy 2018-ban végzett, 122 különböző értékesítővel folytatott interjúsorozatból származik. A kutatás során sikeresen feltártak számos olyan tényezőt, amely végeredményben befolyásolja az értékesítés digitális transzformációját, valamint a köztük lévő kölcsönhatások azonosítására is lehetőség nyílt. Legfontosabb következtetéseik, hogy a technológiai felkészültség, a technológia jellemzői, a tevékenységportfólió, valamint az ügyfélkör mind hatást gyakorolnak az elfogadást végsősoron befolyásoló attitűdre. Mindazonáltal fontosnak tartanak említést tenni a kutatás módszertanából és a minta rendkívül heterogén összetételéből eredő korlátokról, amelyek a jelen kutatás végeredményeként létrejött elméleti modell további tesztelését és elemzését teszik szükségessé.
\end{abstract}

\section{Kulcsszavak: értékesítés, digitalizáció, technológiaelfogadás, technológiai felkészültség}

This study explores the digital transformation occurring within the sales industry. The authors formulate a theoretical model, built upon the Technology Acceptance Model (TAM) and the Technology Readiness Index (TRI), which also incorporates literature focusing on the tools and activities of the sales industry. Their model is based on an empirical study conducted in 2018, involving interviews with 112 different sales representatives. This research identified several factors affecting the digital transformation of the sales industry and pinpoints the interaction between these factors. The most important conclusion to be drawn is that technological readiness, the attributes of technology, the portfolio of activities, and the customer base all influence individual attitudes and, ultimately, affect acceptance. Nevertheless, they find it important to highlight the limitations of the study arising from their methodology and the extreme heterogeneousness of their sample, which make further analyses and tests of their theoretical model necessary.

Keywords: sales, digitalization, technology acceptance, technology readiness

\section{Finanszírozás/Funding:}

A szerzők a tanulmány elkészítésével összefüggésben nem részesültek pályázati vagy intézményi támogatásban. The authors did not receive any grant or institutional support in relation with the preparation of the study.

\section{Szerzők/Authors:}

Pelsőci Balázs Lajosa (balazs.pelsoci@stud.uni-corvinus.hu), PhD-hallgató; Nagy Ákosa (akos.nagy@uni-corvinus.hu), PhD-hallgató; Dr. Gáti Mirkóa (mirko.gati@uni-corvinus.hu), egyetemi docens

a Budapesti Corvinus Egyetem (Corvinus University of Budapest), Magyarország (Hungary)

A cikk beérkezett: 2021. 04. 06-án, javítva: 2021. 06. 10-én, elfogadva: 2021. 07. 21-én.

This article was received: 06. 04. 2021, revised: 10. 06. 2021, accepted: 21. 07. 2021. 
A jelenleg is zajló digitális transzformáció várhatóan olyan társadalmi és gazdasági változásokat eredményez majd (pl. a munkavégzéshez szükséges képességportfólió átalakulásának, BigData és mestereséges intelligencia alapú piackutatás, vagy a biztonsági kockázatok növekedésének megjelenésével, WEF, 2019; WEF, 2020), amelyek alapjaiban véve alakítják át a vásárlók és vállalatok mindennapi életét. Éppen ezért kiemelkedően fontos a versenyképesség megőrzésének érdekében, hogy a vállalatok lehetőségeikhez mérten minél hatékonyabban tudják követni az említett átalakulás folyamatát. Vial (2019) ezt összefoglalóan a dinamikus képességek (dynamic capabilities) és az integratív képességek (integrative capabilities) fejlesztésében látja.

Kutatásunk empirikus tartalmának sajátossága, hogy az értékesítők közvetlen világára koncentrál, így az ügyfélkör interakcióit értelmezve betekintést nyújt az olyan gyakorlati elemekbe, amelyek rávilágíthatnak, hogy a digitális átalakulás során hogyan zajlik az értékesítés tényleges technológiai átalakulása és hogyan élik meg azt az értékesítők.

Singh és szerzőtársai (2019) szerint prognosztizálható, hogy a jövő technológiai újításai jelentősebb hatást gyakorolnak majd az értékesítési folyamatra, mint azok, amelyeket eddig ismertünk. Ilyen a mesterséges intelligencia széles körü elérhetősége és az általa teremtett lehetőségek tárháza. Ez igazolhatja Syam és Sharma (2018) azon megállapítását is, hogy a jövőben az értékesítési technológia akár döntéshozói szerepet is betölthet az eddigi döntéstámogató funkciói mellett, amelyre a szerzők szintén a mesterséges intelligencia értékesítésre gyakorolt hatásait említik.

De a konkrétumok szintjén hogyan is értelmezhető mindez az értékesítés kontextusában? Egyrészt várható a vásárlói magatartás és ebből kifolyólag az értékesítési folyamat drasztikus átalakulása. A digitalizáció által biztosított megoldások lehetőséget teremtenek arra, hogy a vásárlók eddig még nem látott mértékü információhoz férjenek hozzá és ezáltal erősítsék pozíciójukat a vásárlási aktusban. Ez egyértelműen magával vonja az értékesítési folyamatban betöltött szerepek átrendeződését. Az értékesítők feladata jelen példa esetében az, hogy támogassák a vásárlóikat abban, hogy egyes folyamatelemeket és tevékenységeket képesek legyenek önállóan is teljesíteni, azaz, hogy felhatalmazzák és kiszolgálják önmagukat (Mahlamäki, Storbacka, Pylkkönen \& Olaja, 2020). Ugyan ez első ránézésre úgy tünhet, mintha az értékesítőket hoszszabb távon feleslegessé tenné a vásárlási folyamatban, azonban erre érdemesebb úgy tekinteni, hogy a folyamat egyes elemeinek és felelősségeinek vásárlókra helyezésével az értékesítők lehetőséget kapnak arra, hogy fejlesszék önmagukat és a tevékenységük azon elemeit, amelyeket a vásárlók várhatóan a digitális megoldások további bővülése esetén sem tudnak majd önállóan elvégezni.

Ezt a megközelítést Park, Kim, Dubinsky és Lee (2010) kutatási eredményei is megerősítik. Kutatásuk során arra jutottak, hogy az értékesítési folyamat automatizálása - amely bizonyos feltételek teljesülése mellett értelmezhető úgy is, hogy az értékesítő helyett a vásárló látja el az értékesítő egyes tevékenységeit - abban jelent igazi előnyt és újdonságot, hogy az értékesítők képessé válnak arra, hogy folyamatosan alkalmazkodjanak és változtassák azt, hogy hogyan is értékesítenek. Az egyes, vásárlók által is elvégezhető folyamatelemek kiiktatásával biztosítható, hogy az értékesítők több időt fordítsanak a tanulásra és fejlesszék adaptív értékesítési képességeiket, amelyek végül a teljesítmény növekedését eredményezik.

Másrészt, a vásárlók felhatalmazása mellett várható az értékesítői eszköztár jelentős mértékű bővülése is, amely szintén a hatékonyság növekedését vonja maga után. Rodriguez és Boyer (2020) kifejezetten a koronavírusjárvány-helyzet által előtérbe került technológiák pozitív hatásaival foglalkozik. Eredményeik a mobil CRM (mCRM) rendszerek példáján keresztül alátámasztják a különböző technológiai újítások értékesítési kontextusban történő alkalmazásának előnyeit. Vizsgálódásaik során úgy találták, hogy az mCRM-rendszerek segítségével az értékesítők jelentősebb mértékben voltak képesek adaptív értékesítési kompetenciáik alkalmazására, hiszen jobban alkalmazkodhattak az eltérő fogyasztói igényekhez, amelyek végsősoron szintén a hatékonyság növeléséhez vagy fenntartásához vezettek.

Összességében tehát elmondható, hogy az értékesítési kontextusban alkalmazott különböző digitális újítások mind vásárlói, mind értékesítői perspektívából vizsgálva jelentős hatást gyakorolhatnak az értékesítési folyamatra és tevékenységrendszerre. Fontos azonban szem előtt tartani azt a tényt, hogy a technológiai újítások implementációja önmagában nem eredményezi a folyamat hatékonyságának javulását, ahhoz az implementáció mellett szükséges az értékesítői adoptáció is (Morgan \& Inks, 2001).

Az utóbbi gondolatnak megfelelően határoztuk meg e kutatás tényleges fókuszát és az egyes kutatási kérdéseket, melyek mindegyike végsősoron arra vonatkozik, hogy mi befolyásolja az értékesítőket abban, hogy ténylegesen elfogadják és munkájuk során megfelelően használják az egyes technológiai újításokat. Ennek megértéséhez elengedhetetlen a korábban részletesen tárgyalt következmények feltárása és ismerete, azonban ezek további vizsgálata nem tartozik jelen tanulmány közvetlen fókuszába, így ennek megfelelően is viszonyul hozzájuk a kutatás szerkezete.

\section{Szakirodalmi áttekintés}

A TAM-modell alapvetően Fishbein és Ajzen (1980) indokolt cselekvés elméletére (Theory of Reasoned Action; TRA) épül, amely alapján az emberi cselekvés kiváltója az egyéni attitűd és a szubjektív normák által befolyásolt cselekvési szándék. Tehát a cselekvő magatartás e megközelítés alapján minden esetben egy tudatos és átgondolt folyamat eredménye. Davis (1986) első TAM-modelljében ezt a megközelítést a következőképpen értelmezi. Az új technológiák használatának feltétele a használatra vonatkozó cselekvő szándék, amelyet az egyén használatra vonatkozó attitűdje befolyásol. A modellben az attitűdre további két tényező közvetlen hatást gyakorol, ezeket a té- 
nyezőket Davis (1986) észlelt hasznosságként (Perceived Usefulness; PU) és a használat észlelt könnyebbségeként (Perceived Ease of Use; PEU) nevezte el. Az egyszerü magyarázat alapján az észlelt hasznosság annak mértéke, hogy a felhasználó szerint az adott technológia használata mennyiben alkalmas az adott tevékenység hatékonyabb elvégzésére, míg a használat észlelt könnyebbsége annak mértéke, hogy a felhasználó mennyire tartja idő-és energiaigényesnek az új technológia használatának elsajátítását. Itt fontos azt is megjegyezni, hogy a TAM-modell alapján a használat észlelt könnyebbsége az általa gyakorolt közvetlen hatás mellett az észlelt hasznosságon keresztül további közvetett hatást gyakorol a felhasználói attitüdre. Ez azt jelenti, hogy a könnyebben elsajátíthatónak észlelt technológiát a felhasználók hasznosabbnak is észlelik, hiszen hamarabb élvezhetik annak elönyeit.

Bár a TAM-modell elméleti és gyakorlati hozzájárulása elvitathatatlan, az évek során a szakirodalom számos kritikát fogalmazott meg a modellel szemben, melyek döntő többsége az egyszerüségre és a modell magyarázó erejére vonatkozik. Ezeket a hiányosságokat igyekszik ellensúlyozni a modell több különböző kibővített, átalakított változata, így a TAM 2 (Venkatesh \& Davis, 2000), a TAM 3 (Venkatesh \& Bala, 2008), vagy éppen a UTAUT-modell (Unified Theory of Acceptance and Use of Technology) (Venkatesh, Morris, Davis \& Davis, 2003). Az itt felsorakoztatott modellek jellemzően csak néhány magyarázó változóval egészítik ki a TAM-modellt, tehát Fishbein és Ajzen (1980) indokolt cselekvés elmélete továbbra is központi marad az új technológiák elfogadásáról alkotott elméletek ezen csoportjában.

$\mathrm{Az}$ értékesítés és az értékesítésmenedzsment kontextusában szintén számos forrásanyag támaszkodik a TAM-modellre. Az új technológiához kötődő észlelt hasznosság tekintetében egyetértés mutatkozik a különböző források között, tehát az észlelt hasznosság kiemelkedő szerepet játszik abban, hogy az egyes értékesítők elfogadják az értékesítési tevékenységhez kötődő új technológiákat (Avlonitis \& Panagopoulos, 2005; Buehrer, Senecal \& Pullins, 2005; Schillewaert, Ahearne, Frambach \& Moenaert, 2005; Robinson, Marshall \& Stamps, 2005a; Homburg, Wieske \& Kuehnl, 2010). Egyes szerzők megerősítik a TAM-modell alapvetéseit, vagyis szerintük az észlelt hasznosság és a használat észlelt könnyebbsége egyaránt fontos (Avlonitis \& Panagopoulos, 2005) és a használat észlelt könnyebbségének észlelt hasznosságon keresztül kifejtett indirekt hatása is visszaigazolásra kerül (Robinson et al., 2005a). Más források értékesítési kontextusban inkább az észlelt hasznosság dominanciáját tárgyalják (Homburg et al., 2010; Schillewaert et al., 2005), ami nagy valószínűséggel szoros összefüggésben lehet a technológia elfogadásával járó észlelt és valós teljesítménynövekedéssel (Ahearne et al., 2007; Avlonitis \& Panagopoulos, 2005; Buehrer et al., 2005), ami az értékesítői tevékenység sajátosságaival magyarázható. Schillewaert és szerzőtársai (2005) többek között azt is megjegyzik, hogy az értékesítők hajlandók elfogadni egy valamivel bonyolultabb technológiát, hiszen az egyszerű használat nem kárpótol a gyengébb teljesítményért. Szintén az észlelt hasznosság és a használat észlelt könnyebbségének viszonyrendszerében jelenik meg az a disszonancia, amely szerint a menedzsment sokszor tévesen túlbecsüli az egyes technológiák használatának észlelt könnyebbségét és a napi müködésbe történő integrálással járó különböző munkavállalói erőfeszítéseket, ami így hátráltathatja az elfogadást (Gohmann, Guan, Barker \& Faulds, 2005). Ez a gondolat megjelenik Rangarajan, Jones és Chin (2005) munkájában is, akik a komplexitásból eredő bizonytalanság és az implementációval járó erőfeszítések mentén keletkező értékesítői stresszt vizsgálják. A menedzsment és az értékesítők között fellépő, az új technológiák elfogadásához kötődő dichotómiával foglalkozik számos további forrás, amelyek alátámasztják, hogy sokszor a TAM-modell tényezői a hierarchiában felfelé haladva alkalmasabbak az elfogadás tényleges előrejelzésére (Homburg et al., 2010) és menedzsment gyakran jelentősebb produktivitást és nagyobb nyereséget remél az új technológiák bevezetésétől (Gohmann et al., 2005).

Az utóbbi gondolat rávilágít egy, az elfogadást jelentősen befolyásoló tényezőcsoportra, vagyis a menedzsment szerepére, magatartására és eszköztárára. Több forrás is alátámasztja, hogy a vezetők elköteleződése és a technológia elfogadására vonatkozó hajlandósága hatással van az értékesítők elfogadási attitüdjére még akkor is, ha jellemzően nincs szoros kapcsolat a vezetőség és az értékesítők között. Az elfogadást az támogatja leginkább, ha mind a felső vezetés, mind pedig az operatív vezetők egyaránt elfogadóak az új technológiával szemben (Cascio, Mariadoss \& Mouri, 2010; Homburg et al., 2010). Ugyanezen témakörhöz kapcsolható az elfogadást hátráltató tényezők együttese, ami egyaránt vonatkozik az értékesítők félelmeire és a menedzsment helytelen magatartására. Ennek megfelelően, ha a vezetőség nem tisztázza, hogy pontosan mit vár egy új technológia bevezetésétől és az hogyan befolyásolja majd mind az értékesítési, mind pedig az általános vállalati folyamatokat, az értékesítők lassabban, vagy akár egyáltalán nem fogadják el az új technológiát (Avlonitis \& Panagopoulos, 2005; Bush et al., 2005; Morgan \& Inks, 2001). Ezt egészítenénk ki azzal a megállapítással, hogy számos vezető még mindig nem képes pontosan megfogalmazni, hogy mit is értenek a digitális átállás alatt és azt, hogy mit várhatnak egy adott technológia bevezetésétöl (Bencsik, 2021). Szintén ide kapcsolható az értékesítők különböző félelmeihez kapcsolódó vezetői magatartás, amikor egy technológiai újítás során a vezetők túlzott mértékü kontrollt kívánnak gyakorolni a beosztottjaik fölött. Ez megjelenhet mikromenedzsment, megfigyelés és túlzott mértékű elszámoltatás formájában, vagy úgy is, hogy az értékesítőket kihagyják a technológia adoptációjából és implementációjából. Ez a hatás csökkenthető a változások és elvárások transzparens kommunikációjával, az elfogadáshoz kötődő megfelelő jutalmakkal, a teljesítményértékelési szempontok ideiglenes módosításával (Ahearne, Lam, Mathie \& Bolander, 2010) és természetesen azzal, hogy a menedzsment folyamatos támogatást nyújt az elfogadás során és bevonja a folyamatba az értékesítőket mint felhasználókat is (Gohmann et al., 2005; 
Bush et al., 2005; Robinson et al., 2005a; Morgan \& Inks, 2001; Bush, Bush, Orr \& Rocco, 2007).

Egy további tényező, amely gazdagítja a menedzserek technológiaelfogadást ösztönző eszköztárát, ez pedig a tréning és az oktatás biztosítása, ami szoros összefüggésben van a technológiaelfogadás másik pillérének is számító elmélettel, a technológiai felkészültség indexével (Technology Readiness Index, TRI) (Parasuraman, 2000). A szakirodalom újabb forrásaiban sokszor találkozhatunk a digitális érettségi modell (DÉM) elnevezéssel, amely a TRI-hez hasonló célt szolgál, de már inkább fókuszál arra, hogy folyamatában nézze az átalakulást, míg a TRI csak a folyamat elejét elemzi (Gubán \& Sándor, 2021).

A TRI annak mérőszáma, hogy a felhasználó az adott technológiát milyen mértékben lesz képes elsajátítani és a mindennapi feladatainak elvégzéséhez, kitüzött céljainak eléréséhez használni (Parasuraman, 2000). Az index lehetőséget teremt továbbá arra is, hogy felhasználói csoportokat képezzünk és ezáltal racionalizáljuk egy új technológia bevezetésének folyamatát (Parasuraman \& Colby, 2015). A szerzőpáros tanulmányában ilyen csoportként azonosítja a szkeptikusokat, a felfedezöket, az elkerülöket, az úttörőket és a bizonytalanokat. Ez a felosztás számos hasonlóságot mutat az innovációelfogadás különböző csoportjaival, amelyekre számos további forrás is építkezik. Ez alapján megkülönböztethetünk innovátorokat, korai elfogadókat, korai többséget, késői többséget és lemaradókat. Az egyes csoportok különböznek többek közt az információkeresési szokásaik és a kockázatvállalási hajlandóságuk alapján. Az innovátorok jellemzően azok a felhasználók, akik keresik az újdonságokat és hajlandók elsőként kipróbálni azokat, míg a korai elfogadók már igénylik azt, hogy létezzen fellelhető felhasználói tapasztalat az adott innovációval kapcsolatban. Így haladva tovább a korai többség és a késői többség között éri el az innovációs életciklusgörbe az inflexiós pontját, így a lemaradók csoportja már csak az innováció hanyatló szakaszának végén feltételesen fogadja el az adott innovációt (Rogers, 1995). Figyelembe véve az értékesítés B2B dominanciáját fontosnak tartjuk még megemlíteni Moore (1999) munkáját, aki az említett innovációelfogadási csoportokat nem személyekre, hanem egész szervezetekre értelmezve alakította ki. Érthető, hogy a vállalatok esetében nem folytonos az innovációs életgörbe felívelése, és sokszor a lemaradók egyáltalán nem fogadják el az adott innovációt. És bár az értékesítés során bevezetett új technológiák nem feltétlenül tekinthetők innovációnak, az innovációelfogadás még egy jelentős gondolati elemét fontosnak tartjuk megemlíteni, ami az innováció azon jellemzőit veszi sorra, amelyek befolyásolhatják az egyén innovációelfogadási hajlandóságát. Rogers (1995) alapján összesen öt ilyen tulajdonság azonosítható, amelyből az innováció relativ elönye, kompatibilitása, kipróbálhatósága és megfigyelhetősége erősíti az egyéni innovációelfogadási hajlandóságot, míg a bonyolultság visszatarthatja az egyént attól, hogy egy innovációt elfogadjon és implementáljon.

De hogyan is kapcsolódik ez az értékesítéshez kötődő új technológiák bevezetéséhez és a korábban említett oktatáshoz és tréninghez? Egyrészt, a szakirodalom említést tesz arról, hogy az innovatív személyiséggel rendelkező (tehát Rogers (1995) alapján az információt jobban kereső, az újdonságok iránt nyitottabb és a kockázatot nagyobb mértékben vállaló) értékesítők hamarabb fogadják el az új technológiákat és azokat hatékonyabban is tudják használni saját teljesítményük növelésére (Avlonitis \& Panagopoulos, 2005; Robinson, Marshall \& Stamps, 2005b; Schillewaert et al., 2005). Másrészt, azt sem szabad figyelmen kívül hagyni, hogy a technológia bonyolultsága, a technológiával szembeni szkepticizmus sokkal erősebb negatív hatást fejthet ki az elfogadás folyamatára, amit a menedzsmentnek mindenképpen kezelnie kell. Ilyen szkepticizmus lehet például a korábban említett félelmek bizonyos csoportja (Bush et al., 2007), az értékesítő egyéni és elvitathatatlan tudásának és eszköztárának veszélybe kerülése (Bush et al., 2005), vagy például a technológia megtanulásába fektetett idő és az ennek kapcsán észlelt teljesítménycsökkenés (Buehrer et al., 2005; Obal \& Morgan, 2018).

A menedzsment elköteleződése és a technológiára irányuló pozitív attitüdje mellett a szakirodalom leggyakrabban a folyamatos és szervezett tréninget említi az felsorolt kihívások leküzdésére. A kérdést vizsgálva alátámasztható, hogy a technikai feltételek mellett az emberi erőforrás ezen tényezői jelentik a legnagyobb kihívást a menedzsment számára a digitális átállás sikeres implementációja során (Bencsik, 2021). Egyes források alapján számos helyzetben a tréning bizonyult a leghatékonyabb használati ösztönzőnek (Speier \& Venkatesh, 2002) és azokban az esetekben, ahol az értékesítők számára nem volt elérhető a folyamatos támogatás, a befektetés megtérülési rátája (ROI) is jelentősen romlott (Buehrer et al., 2005), míg más források az innovációelmélet során bemutatott fogalmaknak is megfelelő jelenségeket említenek, így a megfigyelhetőséget (Ahearne et al., 2007) vagy a kipróbálhatóságot (Gohmann et al., 2005), amelyek a használat észlelt könynyebbségét is javítják (Schillewaert et al., 2005). Fontos szempont lehet továbbá az értékesítők munkában eltöltött ideje, életkora és tapasztalata (Singh, Marinova \& Sing, 2020).

Mindezek mellett pedig az értékesítők technológiai felkészültsége alapvetően determinálhatja azt, hogy milyen ügyfélkörrel dolgoznak, és ezáltal milyen ügyfeleket vonzanak az értékesítők. Ha azt tekintjük, hogy például a Sales Force Automation (SFA), valamint a mesterséges intelligencia (Artificial Intelligence: AI) milyen új megoldásokkal álltak elő, amelyek korábban nem ismert lehetőségeket teremtettek az ügyfelek kiszolgálásában (ld. bővebben: Singh et al., 2019), úgy érthető, hogy a magasabb technológiai felkészültséggel rendelkező értékesítők szinte mintegy rátalálnak a rájuk nyitott vevőkörre és fordítva, hiszen mindezen technológiák képesek lehetnek a vevői érték, valamint a vevői elégedettség növelésére, ami ezáltal visszahat az értékesítői attitűd alakulására.

Összefoglalva tehát az új technológiák elfogadása és elfogadtatása során nem elegendő kizárólag a technológia pozitív tulajdonságaira fókuszálni, a folyamat sokkal öszszetettebb. A siker egyszerre követeli meg a menedzsment elköteleződését, valamint etikus és transzparens magatar- 
tását, illetve az implementációs folyamat során biztosított támogatást és az értékesítők egyéni pozitív attitűdjét, magatartását és kompetenciáit. Fontos továbbá az is, hogy a különböző technológiák stratégiába ágyazottan kerüljenek alkalmazásra, ugyanis a rendszerszintű kompatibilitás nélkül a várt haszon nem jelentkezhet (Bauer, Mitev \& Gáti, 2019).

Végül fontosnak tartjuk megemlíteni az értékesítés technológiai fejlesztésének formáit és felhasználási lehetőségeit, hiszen ezek mind a TAM-modellhez, mind pedig a TRI-hez szorosan kapcsolódnak. A különböző eszközöket Taiminen és Karjaluoto (2015), a felhasználási lehetőségeket pedig Chaffey és Smith (2013) alapján kívánjuk vizsgálni.

Taiminen és Karjalouto (2015) alapján megkülönböztethetjük az értékesítési eszközöket interaktivitásuk (egy- vagy kétoldalú), illetve a vállalat által gyakorolható kontroll (alacsony vagy magas) alapján. Egyoldalúként értelmezhetünk olyan hagyományos csatornákat, mint egy weboldal, hírlevél, kétoldalúként pedig a vállalati blogokat, egyéb, a vállalat által üzemeltetett közösségi platformokat, vagy például a CRM-rendszereket, esetleg a mobil CRM-rendszereket (mCRM), amelyek a COVID-19 járványhelyzet következtében kiemelkedő érdeklődésnek örvendtek (Rodriguez \& Boyer, 2020). Ezen a területen leginkább a fogyasztói dialógusokba fektetett erőforrások mértéke merülhet fel, mint megfontolandó tényező, egyes fogyasztói csoportok ugyanis kifejezetten soknak is tekinthetik a tranzakción felüli kontaktust, így releváns ,,történetmesélés" nélkül pedig plasztikusnak hathat a vállalat kommunikációja. A kontroll mértéke leginkább kockázati tényezőként értelmezhető, ugyanis például egy alacsony kontroll által jellemezhető közösségimédia-felületen való megjelenés által a vállalat részben külső szereplők kezébe helyezi a márkája formálását. Ezzel szemben egy keresőmotor-optimalizációs (SEO) tevékenység kiszámíthatatlan nyereséggel, azonban alacsony kockázattal bír. Az egyes technológiák további felhasználási irányelveiröl Sharma és Sheth (2010) munkája szolgáltat értékes információkat, akik a különböző szolgáltatási vonalaknak megfelelően kategorizálják azokat.

Chaffey és Smith (2013) 5S megközelítése alapján ezek a megoldások használhatók eladásnövelésre (Sell), értéknövelésre (Serve), párbeszéd kezdeményezésére (Speak), megtakarításra (Save), továbbá márkaépítésre is (Sizzle). Fontosnak tartjuk azonban, hogy az alkalmazás technikai dimenziói mellett annak absztrakt szinten történő értelmezéseit szintén ismertessük. Az 5S megközelítés eladásnövelésre (Sell) és értéknövelésre (Serve) vonatkozó elemei nehezen elkülöníthetők alá- és fölérendeltségi viszonyuk miatt. A marketing és így az értékesítés régóta regnáló megközelítése szerint a marketing célja nem az egyszeri tranzakciós aktus, hanem a tartós kapcsolatépítés a fogyasztóknak teremtett értéken keresztül. Ez alapján tehát az eladásnövelésnek ma már feltétele az értéknövelés. De hogyan is valósulhat ez meg az egyes technológiai újítások implementációjával? A különböző technológiai újítások értékesítési kontextusban történő alkalmazása egyfelöl segíti az értékesítőket abban, hogy fejlesszék célzási (tar- geting) képességeiket, amelynek segítségével valóban az arra nyitott vevőket találhatják meg az általuk kínált értékajánlattal (Ahearne et al., 2007). Másfelől az értékesítők fejleszthetik adaptív értékesítési képességeiket, amely eredményeképpen jobban reagálhatnak a fogyasztók folyamatosan változó igényeire és egyéb jellemzőire (Park et al., 2010; Robinson et al., 2005a). Mindez összességében azt eredményezi, hogy az értékesítőknek lehetőségük nyílik arra, hogy pontosabb értékajánlatot fogalmazzanak meg alacsonyabb költség mellett, amely növelheti mind az ő hatékonyságukat, mind a fogyasztónak teremtett értéket.

Azon értékesítők között, akik számára a technológia fontos eleme a mindennapi tevékenységeinek (pl. SFA, CRM-rendszerek, közösségimédia-platformok értékesítési célú felhasználása stb.), valamint érvényes ezen eszközök célhoz rendelt, professzionális alkalmazási képessége (ld. Parasuraman, 2000), ott feltételezhetö, hogy a technológiai felkészültség - ezen cikk értelmezésében a TRI-mérőszám - összefüggésben áll azzal, hogy az értékesítői munkakörben dolgozók ténylegesen milyen technológiákat használnak munkájukhoz, és e technológiák használatának milyen fázisában vannak, hasonlóan Parasuraman és Colby (2015) megközelítéséhez, értékesítői kontextusba helyezve. Ennek következtében az alábbi kérdésre keressük a választ:

\section{KK1: Hogyan hat a technológiai felkészültség az alkalmazott technológiai jellemzökre?}

Értékesítői kontextusban a technológiai felkészültség alapvetően rendelkezik szervezeten belüli és szervezeten kívüli hatásokkal. Szervezeten belüli hatásnak minősülhet az értékesítőkre, ill. az értékesítői szervezet müködésére kifejtett hatásmechanizmusok köre, szervezeten kívüli hatásként pedig megemlíthető az értékesítési szervezet érintettjeire, kiemelt értelemben pedig a vevőire gyakorolt hatás vizsgálata. Singh et al. (2019) megközelítését alapul véve, az ügyfelek kiszolgálásának új megoldásai a meglévő ügyfélkörre is hatással lehetnek, de egyúttal új, innovatív vevőkört vonzhatnak az értékesítési szervezethez. Ebből fakadóan a következő kérdésre keressük a választ:

\section{KK2: Hogyan befolyásolja a technológiai felkészültség az értékesítöi ügyfélkört?}

Az elméleti szakaszban vizsgált technológiaelfogadási modellek értékesítői kontextusba ágyazva sok esetben vizsgálják azt, hogy a technológiaelfogadási hajlandóság kihat az értékesítők elfogadással összefüggő attitüdjére. Ez a gondolat összefüggésben van Robinson et al. (2005a) gondolataival, akik a technológia egyes jellemzőit (használat észlelt könnyebbsége, észlelt hasznosság) hozzák összefüggésben az elfogadási hajlandósággal és attitűddel. Az észlelt hasznosság dominanciája, összefüggésben a várt teljesítménynövekedéssel (ld. Ahearne et al., 2007) előfeltételezi, hogy a technológia egyes jellemzői különféleképpen hatnak az értékesítők hozzáállására. Ezért a következő kérdést tesszük fel:

KK3: Hogyan befolyásolják a technológia jellemzői az attitüdöt? 
Egy értékesítési szervezet ügyfélköre - föként szervezetközi piaci szituációban - kialakíthat olyan igényeket, amelyek mentén elvárják bizonyos digitalizált, innovatív technológiai megoldások alkalmazását értékesítési tevékenységeikhez, amellyel őket kiszolgálják (pl. AI használata az értékesítési tevékenységben). Amíg Singh et al. (2019) az ügyfélkör kiszolgálásának minél sokrétübb megoldásait taglalja, úgy feltételezhető, hogy az innovatív vevőkör is hatással van az értékesítők digitalizációhoz való hozzáállására, hiszen ezen ügyfelek kimondott vagy látens igényei előfeltételezhetik az értékesítői csoport pozitív hozzáállását új, korszerü eszközökhöz. Ez alapján a következő kérdésre keressük a választ:

\section{KK4: Hogyan hat az ügyfélkör az attitüdre?}

Az értékesítők alkalmazkodása a digitalizációs folyamatokhoz elengedhetetlen (Morgan \& Inks, 2001), és ez a feltétel mindinkább igaz a jelenlegi, innovatív technológiák megjelenésével párhuzamosan. Egy értékesítési szervezet számára a digitális átalakulás nem az egyén szintjén zajlik, annak csak részeleme, hogy maga az értékesítő személyesen hogyan áll hozzá az átalakuláshoz, sok esetben a döntések meghozatala a menedzsment szintjén történik meg. Homburg et al. (2010) említi a menedzsment és az értékesítők között fellépő dichotómia kérdéskörét, ez alapján pedig feltételezhető, hogy a menedzsment hatással van a tényleges technológiahasználatra, azonban nem hanyagolható el az sem, hogy foglalkozzunk az értékesítők félelmeivel és fenntartásaival a digitalizáció kapcsán, hiszen ők lesznek az új technológiák tényleges használói (ld. Avlonitis \& Panagopoulos, 2005; Bush et al., 2005; Morgan \& Inks, 2001). Emiatt fontos megvizsgálni a következő kérdést:

\section{KK5: Hogyan hat az attitüd a digitális átalakulásra?}

$\mathrm{Az}$, hogy egy értékesítési szervezet milyen szinten alkalmaz digitalizált megoldásokat, és ezt mennyire várja el értékesítőitől, nagyban befolyásolhatja, hogy az értékesítők milyen felkészültséggel rendelkezhetnek az adott technológia kapcsán (pl. milyen TRI-vel rendelkeznek). Ebből a szempontból a technológia bevezetésének folyamata, illetve annak egyes lépcsőfokai előfeltételezik, hogy az értékesítő számára milyen oktatásokat, tréningeket szervez a menedzsment, ezáltal előkészítve őket a technológia professzionális felhasználására (ld. Cascio et al., 2010).
A szakirodalom releváns megállapításai alapján a következő kérdés vizsgálata merült fel:

\section{KK6: A digitális átalakulás hogyan hat vissza a technológiai felkészültségre?}

A megfogalmazott kutatási kérdéseket az elmélet szintetizálásával összhangban egy javasolt elméleti keretrendszerbe rendeztük, amely ismertetésére a következő bekezdésben sor kerül. Azt azonban fontosnak tartjuk megjegyezni, hogy a kutatás feltáró, kvalitatív jellegéből eredendően az empirikus eredmények bemutatása nem követhette teljes mértékben a kérdések struktúráját. Ennek oka az is, hogy a modell egyes elemei egymással átfedésben vannak, így jelenleg nem határolhatók el szigorú pontossággal. A kutatási kérdésekre az eredmények bemutatása során a következő úton kapunk választ:

- KK1: A technológiai felkészültség kihívásai és a digitális átállás potenciális válaszai és A jelenleg alkalmazott digitális megoldások, különös tekintettel az ügyfélkör szerepére alfejezetek,

- KK2: A technológiai felkészültség kihívásai és a digitális átállás potenciális válaszai, A technológiai felkészültség és a digitális átállás jelenlegi helyzete az értékesítésben és A technológiaelfogadás iránti pozitív attitüdöt megalapozó feltételek alfejezetek,

- KK3: A technológiaelfogadás iránti pozitív attitüdöt megalapozó feltételek és A technológiaelfogadás iránti negatív attitüdöt eredményező feltételek alfejezetek,

- KK4: A technológiai felkészültség kihívásai és a digitális átállás potenciális válaszai, A technológiai felkészültség és a digitális átállás jelenlegi helyzete az értékesítésben, A technológiaelfogadás iránti pozitív attitüdöt megalapozó feltételek és A technológiaelfogadás iránti negatív attitüdöt eredményező feltételek alfejezetek,

- KK5: A jelenleg alkalmazott digitális megoldások, különös tekintettel az ügyfélkör szerepére alfejezet,

- KK6: A technológiai felkészültség és a digitális átállás jelenlegi helyzete az értékesítésben alfejezet.

Az elmélet szintetizálásaként konceptuális modellünket az 1. ábrán a következőképpen ábrázoltuk:

\section{Az értékesítés digitális transzformációját befolyásoló tényezők konceptuális modellje}

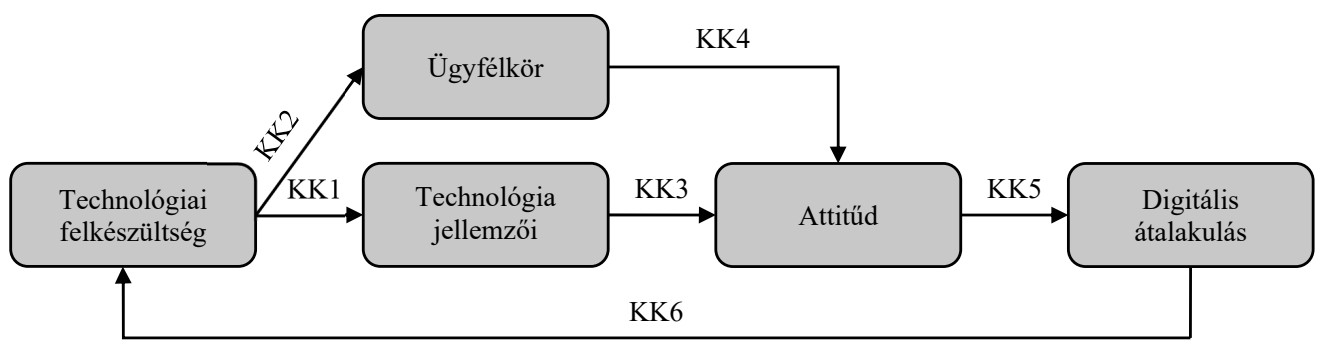


Kutatási kérdéseink megfogalmazása során többszempontú elvárást fogalmaztunk meg az elméleti hozzájárulás tekintetében. Egyfelől azt várjuk az eredményeinktől, hogy egy olyan konceptuális keretrendszert alapozhatunk meg velük, amely egy későbbi kvantitatív tesztelést követően arra is alkalmas lehet, hogy fókuszált kutatások elvégzésére alkalmazzák. Másfelől az előzetes modellbe bekerült elemeket azért is kapcsoltuk össze ilyen módon, mert úgy találtuk, hogy a szakirodalom még mindig fragmentáltságot mutat a tekintetükben, vagyis az egyes elemek és a köztük fennálló kapcsolatok önállóan, vagy a javasolt keretrendszer egyes blokkjai fellelhetők az irodalomban, de azok ilyen formában történő, átfogó összekapcsolása még nem azonosítható egyértelmüen. Végül, de nem utolsósorban elméleti hozzájárulásként fogalmaztuk meg azt is, hogy a modell egyes elemei árnyaltabb képet kapjanak, a hozzájuk kapcsolódó önálló tudásanyag bővüljön.

\section{Módszertan és mintajellemzők}

Kutatásunkat egy 2018-ban végzett szakértői mélyinterjúk eredményét tartalmazó adatbázisra alapoztuk, mely segítségével összesen 122 értékesítő válaszát elemezhettük. Az alapsokaságot azok az értékesítők képezték, akik Magyarországon végzik tevékenységüket. A mintavétel célja az volt, hogy változatos iparági összetétellel rendelkező értékesítői adatbázis álljon rendelkezésünkre. Ennek megfelelően a válaszadókat a következő iparágakból választottuk ki: ipar (ezen belül: építőipar, feldolgozóipar, könnyüipar, nehézipar, vegyipar, összesen: 23,9\%), kereskedelem (ezen belül: autókereskedelem, egészségügy, elektronika, FMCG, vegyi áru, vendéglátás, öszszesen: 23,3\%), pénzügyi-biztosítási tevékenységek $(13,2 \%)$, szolgáltatás $(12,6 \%)$, ingatlanügyek $(10 \%)$, információ, kommunikáció $(7,5 \%)$, hirdetés, média $(3,8 \%)$, mezőgazdaság (2,5\%), egyéb ( $\mathrm{pl}$. nagykereskedelem, tanácsadás, összesen: $3 \%)^{1}$. Minden egyes mintaalanyt más vállalatból választottuk ki. A vállalatoknak 65,4\%ban budapesti vagy közép-magyarországi telephelyük van, további 6,9\% közép-dunántúli, 5,6\% észak-alföldi, 5\% nyugat-dunántúli, 3,8\% dél-alföldi, a maradék 13,3\% pedig a többi magyarországi régióban rendelkezik telephellyel. A minta vegyesen tartalmaz végfogyasztói (B2C) és szervezetközi (B2B) értékesítőket, illetve olyan vállalatokat is, amelyek vegyesen értékesítenek mindkét piactípusra, de a minta zömében B2B értékesítőkből áll. A mintaalanyok demográfiai jellemzőik alapján a következő mintázatot mutatják: 66\% férfi, 34\% nő, 21-64 év közöttiek. A válaszadók mind értékesítők - vagy értékesítéssel is foglalkozó részleg- vagy vállalatvezetők - voltak. Ezen belül, a mintaalanyok közel 45,6\%-a valamilyen vezető volt (értékesítési vezető: $18,1 \%$, kereskedelmi vezető: $4,7 \%$, ügyvezető: $10,7 \%$, tulajdonos: $3,4 \%$, egyéb vezető: 8,7\%), 28,87\% értékesítő, ezen kívül 8,7\% Key Account Manager (KAM: kiemelt ügyfélkapcsolati menedzser), 6,7\% értékesítő és tanácsadó, 4\% account manager, további értékesítési munkakörben dolgozó pedig 6\%. A mintavételi technika kiválasztásánál nem valószínüségi mintavétel történt, hiszen a mélyinterjús kutatásmódszertan esetén nem volt előzetes elvárás a bármely mintajellemző alapján elérendő reprezentativitás (Kvale, 2008). Az interjúk célja az volt, hogy tárjuk fel az értékesítők digitális átalakulásának befolyásoló tényezőit. Az interjúk félig strukturált formában zajlottak, föként nyílt kérdéseket alkalmaztunk (Turner, 2010).

Az egyes interjúkból történő idézések során a lekérdezők személyazonosságának védelme érdekében sorszámozott kódolást alkalmaztunk. Az egyes interjúk leiratait sorba rendeztük és számkóddal láttuk el (Interjúalany 1.; Interjúalany 2.; ... Interjúalany 122.). Az eredmények bemutatása során az azonos sorszámú jelölés azonos interjúra utal.

Az értékesítők körében feltárandó technológiai felkészültség és az ehhez kapcsolódó attitüdjellemzők kutatása a föleg KKV-k körében végzett hasonló kutatásokban (pl. Taiminen \& Karjaluoto, 2015) jellemzően elemezhető kvalitatív módszertan, azon belül pedig mélyinterjú segítségével, mivel a digitalizálódó értékesítői szakma számára nem mindig a felszínen lévő, explicit attitüdök a mélyinterjú speciális jellemzői segítségével jól feltárhatók (Kvale, 1994).

A kódolás során először külön-külön nyílt kódolási kategóriákat alkottunk, amelyeket rendszerbe foglaltunk és összekapcsoltunk, majd az elmélet megalkotása előtt elvégeztük a keresztvalidációt a kutatói szubjektivitás hatásának csökkentése érdekében (Williams \& Moser, 2019). A keresztvalidáció során először külön-külön kielemeztük az interjúkat és megalkottuk önálló kategóriáinkat, amelyeket elöször szintén külön-külön ellenőriztünk, majd kutatói feljegyzéseink alapján az egyéni percepciók torzító hatását csökkentve, megalkottuk a közös kódolási kategóriákat. Az interjúk mennyisége elég volt az elméleti telítettség eléréséhez, tehát újabb válaszok bevonásával is nehezen találtunk volna újdonságot. A végső elemzést hat kódkategória alapján végeztük el, amely alapján azonosítottuk azokat a kihivásokat, amelyek megoldásában segithet a digitalizáció, azokat a tevékenységeket, amelyeket már digitális eszközökkel végeznek, a használt digitális eszközök körét, valamint a pozitív, semleges és negatív attitüdelemeket, amelyek a digitalizáció elfogadásához kötödnek.

\section{Kutatási eredmények}

\section{A technológiai felkészültség kihívásai és a digitális átállás potenciális válaszai}

Ebbe a kódolási kategóriába kifejezetten olyan területeket soroltunk be, amelyeket fennálló problémaként, fejlesztési lehetőségként említettek alanyaink. Fontos kiemelni, hogy ez a kategória jelentősen kisebb elemszámban jelent meg, ám a digitális felkészültség szempontjából elengedhetetlen volt megjelenítése. A digitalizáció által megoldandóként értékelt kihívásokat belsö müködéssel, külső megfeleléssel, illetve vevökkel kapcsolatos tényezökre osztottuk fel.

Belső működéssel kapcsolatos kihívásnak tekinthetők a vállalati értéklánc elemeit érintő gondok, amelyek

\footnotetext{
Az értékesítők által képviselt vállalatok alkalmazotti létszámának mediánja 45, és összességében tartalmaztak vállalatokat 1 és 7000 alkalmazotti körből is, az alkalmazotti létszámok átlaga összességében 295.
} 
kezelése elsődlegesen vállalati határokon belül történik. Ilyen például az egyes folyamatok bonyolultsága, a készletgazdálkodás vagy éppen a költségoptimalizálás. Átfogó elemként jelenik meg továbbá a folyamatok integrálása. Ezek a szempontok inkább a technológiai felkészültség materiális oldalának befolyására erősítenek rá, amelyek során a vezetés oldaláról kialakított feltételek befolyásolják az értékesítési lehetőségeket (KK1).

\begin{abstract}
"Az lenne az ideális, ha lenne egy tervező szoftverünk, amellyel nagyon könnyen tudnánk mi is használni az ügyfellel, konfigurálni dolgokat. A szoftver kidobná, hogy ez a terv, ehhez ezeket a termékeket lehetne használni, ennyibe kerülnek, ez az elérhetöségük. Egy online, azonnal bevethető tervező szoftver nagyban segítené az eladásokat." (Interjúalany 117.)
\end{abstract}

\section{„Legjobb az lenne, ami most folyamatban van, hogy integrált szoftverünk legyen, hogy ne négy rend- szerben külön legyenek megtalálhatók az informá- ciók." (Interjúalany 83.)}

Külső megfeleléssel kapcsolatos kihívásnak tekinthetők az olyan gyakorlati müködéshez köthető szempontok, mint az ellátási láncban felmerülő anomáliák kezelése, valamint jellemzően olyan kihívások, amelyekre a vállalat nem tud teljes kontrollt gyakorolni, így például a szabályozók által támasztott elvárások összessége. Emellett megjelennek olyan kevésbé kézzelfogható elemek, mint a versenytársakhoz viszonyított pozíció fenntartása. A belső müködéshez hasonlóan ebben az esetben is megjelennek a vezetőség által biztosított feltételek mint korlátok (KK1). Emellett az ügyfélkör hatása is kiemelendő, többek között az exporttevékenység oldaláról vizsgálva (KK2, KK4). Ebben az esetben azonosítható egy köztes elem az ügyfélkörből származtatva, amely a tevékenységi kör, amely megkerülhetetlen kihívásokat állíthat az értékesítők elé, így az ezekhez kötődő folyamatokat egyszerüsítő megoldások pozitívan befolyásolhatják az elfogadási attitüdöt.

\section{„A mi esetünkben az okozza az összetettséget, hogy az Európai Unión belüli és kívüli exportálás eltérő dokumentációt igényel. Ezeknek a folytonos nyomon követése és kezelése nem egyszerü." (Inter- júalany 66.)}

\section{„A központi rendszer nagyon régi, fél óránként fris- síti az adatokat, ami problémákhoz vezethet. Például három raklap kőbányai eladása, ami nincs raktáron, a rendszer nem jelezte időben, hogy a készlet elfo- gyott." (Interjúalany 38.)}

„Illetve ami még jól jönne, az egy összehasonlító szoftver a konkurencia és közöttünk..." (Interjúalany 117.)

Végül, de nem utolsósorban a vevőkkel kapcsolatosnak tekinthető minden olyan kihívás, amely a vevők megszerzésére (üzletkötés, földrajzi távolságok áthidalása, kommunikációs zaj leküzdése stb.) és a jelenlegi vevők megtartására (érdeklődés fenntartása, további értékesítések biztosítása, igények jobb megismerése) vonatkozik. Emellett a kétoldalú kommunikáción felül a márkaépítésben betöltött szerepet is kiemelnénk, megjelent a digitalizáció szerepe a fogyasztói percepciók befolyásolásában, ugyanis egyesek szerint jobb összkép alakul ki, ha egy vállalat a modernitás látszatát képes kelteni (KK2).

\section{„... nemcsak nekünk, hanem az ügyfeleknek sincs kapacitása annyit találkozni velünk, hiszen például elfoglalt ügyvezetőkről beszélünk." (Interjúalany 17.)}

„Sajnos sokszor előfordul, hogy digitális eszközök hiánya miatt nem tudunk elég gyorsan reagálni. Például, ha az ügyfél küld egy tervet, hogy szkenneljük be és adjunk rá árat, az nem mindig megy." (Interjúalany 116.)

„...egy adatbázisunk lenne az ügyfeleikről, így meg tudnánk keresni azokat az ügyfeleket, akiknek a kapcsolattartója már nem dolgozik nálunk." (Interjúalany 95.)

"Szükség lenne rá, hogy digitálisan alá legyen támasztva a márka, mert akármennyire felsőkategóriás vásárlók vannak, a látszat nekik is számít." (Interjúalany 22.)

A válaszok alapján azt találtuk, hogy a megkérdezettek tisztában vannak a jelenleg legfontosabb kihívásokkal, és azt is látják, hogy ezekre a digitalizáció hogyan adhat választ, tehát a technológiai felkészültségük egyik oldalról vizsgálva biztató képet mutat. Másfelől viszont az, hogy a valóság szerint mire használják az egyes megoldásokat, azt mutatja, hogy a tanulási görbe még inkább felfelé ívelő szakaszban van, tehát még van hová fejlődni. Ezt a képet némileg árnyalja, hogy több megkérdezett is a vállalat vezetősége felőli ellenállást, vagy az átalakulás további lépésének előfeltételeként jelentkező korábbi fejlesztés hiányát nevezte meg a digitális átalakulás hátráltató tényezőjeként.

\section{A technológiai felkészültség és a digitális átállás jelenlegi helyzete az értékesítésben}

Ahogy azt említettük, a digitális megoldások jelenlegi alkalmazási területei nem feltétlen mutatnak teljes és kielégítő átfedést azokkal a kihívásokkal, amelyekre a digitalizáció választ adhat. Az egyes válaszok elemzése arra mutat, hogy a tudatos és strukturált, illetve az ad hoc megoldások egyaránt jelen vannak az értékesítési tevékenységrendszerben.

Tudatosnak és strukturáltnak tekinthetünk olyan megoldásokat, mint például a vevői igények mélyebb és pontosabb megismerését célzó alkalmazások, a versenytársak figyelése vagy éppen a belső erőforrás-felhasználás racionalizálása. Ezek jellemzően a vállalati általános stratégiából és annak marketing és kommunikációs részstratégiáiból levezethetők, így jellemző rájuk bizonyos fokú strukturáltság és tudatos tervezés. Ebböl 
következik továbbá, hogy ezek használatában többnyire kevés választási vagy kezdeményezői lehetőséggel rendelkeznek az értékesítők, az eszközök a szervezeti munkafolyamatokba mélyebben beépültek, felülröl standardizáltak (KK6).

\section{„A nemzetközi piacra lépést olyannyira segíti, hogy szerintem a digitális eszközök nélkül meg sem való- sulhatna." (Interjúalany 114.)}

„Ez olyan, mint a ködben való vezetés, régen mentünk a vak világba, most meg teljesen világosan látni mindent." (Interjúalany 14.)

„A tableten veszem fel a rendeléseket, és továbbítom őket a céghez, ahol az adatokat megkapja mind a raktár, mind a pénzügy, mind pedig a számítástechnikai osztály, ahol a forgalmi adatokat követik nyomon." (Interjúalany 4.)

„...ennek a néhány paraméternek az ismeretében mutatok neki akár számítógépen, akár telefonban, akár szóban, akár személyesen mappából ingatlanokat, amelyek megfeleltek az általa körbeírt paramétereknek..." (Interjúalany 119.)

„Csoporton belül, ha valamelyik országban kitalálnak valami okosat, akkor azt igyekeznek átültetni a másik országba is, integrálják a folyamatokat." (Interjúalany 15.)

Ad hoc megoldások lehetnek olyan alkalmazások, amelyek az értékesítők szabad döntésére vannak bízva, így például a tárgyalási folyamatok átalakítása, az időgazdálkodás, vagy éppen a vevőkkel való kapcsolattartási folyamat egy része. Bár az, hogy ezek a megoldások léteznek, jelentősen megkönnyítik az értékesítők munkáját, de ad hoc jellegük miatt hiányzik az a fajta integráltság, ami az összes többi megoldás átfogó támogatását biztosíthatná. Mindazonáltal előnyként jelenik meg, hogy az értékesítők többnyire magasabb befolyással rendelkeznek ezen területek fölött, ami által képesek jobban alkalmazkodni a vevői körük, vagy a praktikus ügyvitelük igényeihez saját hatáskörből (KK4, KK6). Ezen a területen a kontrollvesztés leginkább az egyes felhasználási módok kikerülhetetlenségéből származik, amikor egy-egy eszköz olyannyira általánosság válik, hogy igénytől függetlenül legalábbis rendelkezni kell vele, ha nem is aktívan használni (KK2).

"A telefonom mindig nálam van, így könnyen és gyorsan tudok válaszolni az üzenetekre, ami jelentősen felgyorsítja a kommunikációt." (Interjúalany 88.)

"Ezek a szoftverek, ezek a programok olyan dolgokat tartanak észben, amiket nekem nem feltétlenül kell akkor észben tartanom." (Interjúalany 13.) „....régen az volt, hogy erről érdeklődött, vissza kell hívni, volt idő összegyüjteni, megnézni, most viszont, ha engem felhívnak közvetlenül, akkor nekem rögtön kell tudni..." (Interjúalany 58.)

Az eredmények alapján az egyes megoldások részletessége és elterjedtsége bizonyos tekintetben ellentmondásosnak tekinthető. Egyrészt találhatunk példát a strukturált megoldásokra, amelyek sokkal jobban illeszkednek a vállalati stratégiához, másrészt azonban az egyéni ad hoc megoldások iránt nagyobb elkötelezettséget mutatnak a megkérdezettek. Ez a digitális transzformáció egyes döntési pontjainak, szereplőinek és motivációinak meghatározásában fontos szerepet tölt be. A szegmentálás itt természetesen árnyalhatja az összképet. Bizonyos tevékenységi körökben és nagyobb vállalatméret esetében a standardizáltság nehezen lehet például elkerülhető, míg kisebb ügyfélkörrel rendelkező, a személyességre építő értékesítők esetében a nagyobb szabadság a jellemző.

\section{A jelenleg alkalmazott digitális megoldások, különös tekintettel az ügyfélkör szerepére}

Az értékesítők által alkalmazott digitális eszközöket megkülönböztethetjük megfoghatóság és megfoghatatlanság alapján, funkcionalitás alapján vagy azok egy részét a szakirodalomban is említett egy-és kétoldalú, alacsony és magas vállalati kontroll alapján.

Megfoghatóság és megfoghatatlanság tekintetében azokat az eszközöket értjük megfoghatónak, amelyek tényleges fizikai manifesztációval rendelkeznek, így például a laptop, az okostelefon, a tablet, az aláírópad, vagy akár az interaktív televíziók. Ezzel szemben megfoghatatlannak azokat az eszközöket tekintjük, amelyek valamilyen csatorna létrehozásában öltenek testet, így például a közösségimédia-platformok, a különböző kommunikációs szoftverek vagy akár a CRM (Customer Relationship Management - Ügyfélkapcsolat menedzsment) rendszer. A kettő között van némi átfedés azon szoftvereknél, amelyek immateriális eszköznek minősülnek, de nem hoznak létre új csatornát, így például az irodai szoftverek, vagy például a belső ERP (Enterprise Resource Planning - Vállalatirányítási információs rendszer) rendszerek. E tekintetben azt találtuk, hogy a megkérdezettek jellemzően rendelkeznek az alapvetőnek tekinthető eszközökkel, azonban speciálisabb, bonyolultabb megoldások már jóval kevésbé dominánsok a válaszokban.

„... ha van egy ügyfelem, aki kér egy ajánlatot, akkor úgy indul, felveszem a telefont, belépek a CRM-be, megnézem milyen adatok vannak rajta, belépek az Avalon Online-ba, hogy milyen autóink vannak, mit és milyen áron tudom kiajánlani. Tehát egy feladathoz akár egyszerre négy felületet is használok, de van, amikor egy is elég." (Interjúalany 82.)

„Ügyfeleket lehet megkeresni, célcsoportokat lehet elérni, e-mailes ajánlással személyre szabott ajánlatokat lehet az ügyfeleknek elküldeni." (Interjúalany 77.) 
„...van egy honlap, ahol van egy konfigurátor, ahol meg tudod nézni, hogy mi lenne ennek az autónak a normál ára..." (Interjúalany 39.)

Funkcionalitás szerint megkülönböztethetjük a kommunikációs, a müködéstámogató és a kötelező eszközöket. Utóbbi például szabályozási előírás miatt szükséges, valamint olyan iparághoz köthető eszközöket tartalmaz, mint egy lézeres távmérő, vagy egy 3D modellező program. A kommunikációs eszközök kategóriájába tartozhatnak az olyan egyirányú csatornák, mint a vállalati weboldal vagy hírlevél, az olyan kétoldalú csatornák, mint a digitális ügyfélszolgálat, a közösségimédia-felület, vagy éppen a különböző üzenetküldő alkalmazások. A megkérdezettek elmondása alapján jellemző, hogy a vállalataik igyekeznek a magas vállalati kontroll fenntartására. Bár az utóbbi gondolat explicit módon nem teljesen kiolvasható a válaszokból, az egyes említett eszközök és csatornák Taminen és Karjaluoto (2015) alapján mégis a magas kontroll kategóriába esnek. Ezeknek a csatornáknak a választása az értékesítők hatáskörében jellemzően tudatosan zajlik, a szükségük, vagy előnyeik felismeréséből származik, míg figyelmen kívül hagyásuk esetében a későbbiekben kifejtett, attitüddel kapcsolatos elemek fontos szerepet játszanak (KK1, KK5).

„... ha egy ügyféllel találkozom, mindig tájékozódom például a családi állapotukról, munkájukról, sokszor Facebookon utána lehet keresni, hogy miket kedvelnek." (Interjúalany 94.)

"Gördülékeny a folyamat, az értékesítés részei már egy CRM-ben mennek, az értékesitők nem a saját kényük-kedvük szerint dolgoznak, a rendszer vonalvezetőként funkcionál." (Interjúalany 1.)

„... amíg papíron kellett számolni, dolgozni, addig a folyamat lassú és nehézkes volt. Például az értékesítő nem megfelelően számol, nem ír szépen, ezek mind panaszhoz vezettek. Most az üzletet egyszerüen meg lehet kötni tableten is és ez sokkal jobb." (Interjúalany 73.)

„....sales-es tool van, amivel a készletinformációba bele lehet látni, a vevők projektjeit lehet látni, más üzletágakból információra is rálátást lehet nyerni." (interjúalany 116.)

„...frissítjük az újdonságokat, elküldjük nekik, hogy lássa, hogy foglalkozunk vele." (Interjúalany 19.)

Összességében elmondható, hogy bár az alkalmazott digitális eszközök viszonylag széles palettája jelenik meg a válaszokban, a komplex, alacsony kontroll által jellemzett eszközök jellemzően nem dominálták a válaszokat, az előnyeikkel kapcsolatos részletes tudás pedig inkább a válaszadók egy szükebb rétegére korlátozódott, akik rendszerint a szélesebb vállalati folyamatokkal is aktívan érintkeznek a munkájuk során.

\section{A technológiaelfogadás iránti pozitív attitüdöt megalapozó feltételek}

Kutatásunk során úgy találtuk, hogy a megkérdezett értékesítési szakemberek válaszaiban a pozitív attitűdre mutató elemek dominánsabban jelentek meg, mint azok ellentéte. A válaszok elemzése alapján az egyes visszajelzéseket sikerült különböző csoportokba rendezni, amelyek alapján a következőket találtuk. A technológia jellemzői közül leginkább a gyorsaság, az egyszerüség, a hatékonyság és az interaktivitás került említésre. Ezek mind olyan tulajdonságok a válaszadók szerint, amelyek alapjában együtt járnak a technológiával (tehát jelen kutatás kontextusában Davis (1986; 1989) alapján ezt azonosíthatjuk az észlelt hasznosság egyik aspektusaként) (KK3). Erőteljesen megjelenik az ügyfélkörtől származó elvárások attitüdre gyakorolt hatása is (KK4).

"Az egészen biztos, hogy a digitális eszközök lehetővé teszik, hogy több ügyfelet szolgáljak ki egységnyi idő alatt egyszerre." (Interjúalany 13.)

„Az online kapcsolattartásnak köszönhetően rengeteg dolgot meg tudunk beszélni írásban elöre." (Interjúalany 21.)

„....az, hogy az interneten elérhetőek vagyunk, hogy tényleg egyszerü, átlátható a szerződésnek a leírása, az szerintem hatalmasat tud dobni..." (Interjúalany 26.)

A technológia eredményeit is gyakran említették a megkérdezettek. Ezek közül legtöbbször a belső munkafolyamatok javulása, a vevőkkel való kapcsolattartás, a földrajzi távolságok áthidalása, a vevőszerzés és a vállalati imázs és bizalom javulása került említésre. Ezen kategória egyik speciális aspektusa azok az eredmények, amelyek által a munkavállalók képességei javulnak, így például kevesebb hibát követnek el, magabiztosabban végzik a munkájukat, vagy éppen nagyobb elégedettséget mutatnak a vállalattal szemben, ezek pedig az általános eredményekre hatnak. Ismét megjelenik ezek mellett a digitális felkészültség közvetlen hatása a márkaépítésre, amely az ügyfélkör elvárásain keresztül befolyásolja a további átalakulást (KK2, KK4).

„A digitális eszközök használatával interaktívan tudjuk prezentálni vállalatunk értékeit akár több ezer kilométer távolságból is." (Interjúalany 55.)

„A fiatalokat már nem tudjuk elérni szóban és ehhez kellenek a digitális eszközök. Ezeket a trendeket alkalmazni kell." (Interjúalany 32.)

„... nagyon gyorsan jön az információ, de nem zavarja meg az embert munka közben. Akkor foglalkozom vele, amikor nekem kényelmes." (Interjúalany 83.) 
Az természetesen, hogy ez a megkérdezett csoport jellemzően több pozitívumot emelt ki, mint annak ellentétét még nem feltétlen ad felhatalmazást arra, hogy ebből általánosan messzemenő következtetéseket vonjunk le, hiszen a szereplők heterogenitása és a kutatás kvalitatív jellege miatt a reprezentativitás feltétele nem teljesül.

\section{A technológiaelfogadás iránti negatív attitűdöt eredményező feltételek}

Azok a válaszok, amelyek a technológiával szembeni negatív vagy semleges attitüdre mutattak, kevésbé voltak jellemzőek a mintában. Általánosságban elmondható, hogy ezek a válaszok két csoportra bonthatók, egyéni és ügyféllel kapcsolatos tényezőkre.

Egyéni tényezőként leggyakrabban a technológia személytelenségét, illetve egy nehezen vagy egyáltalán nem megmagyarázható érzést említettek a válaszadók. Utóbbi eredhet abból is, hogy nem volt lehetőségük, vagy nem is akarták kipróbálni a különböző technológiai újításokat, így még nem látják azok gyakorlati hatását, vagy valamilyen olyan egyéni sajátosságból ered, ami további kutatási szempontok vizsgálatával határozható csak meg pontosabban (KK3).

\section{"Az indirekt kapcsolattartás hosszú távon nem kifi- zetődő, mivel nem alakul ki az ügyfél részéről meg- felelő kötődés a vállalat iránt. A személyes kapcso- lattartás elengedhetetlen." (Interjúalany 8.)}

"Tehát hiába írom be a digitális naptárba, én azt vettem észre, hogy akkor halogatom, vagyis nem végzem el az adott feladatot az adott napon, akkor ott csak így gyülik..." (Interjúalany 101.)

\section{"Nem érzem magamat a mai, modern világ gyerme- kének olyan szinten, hogy ezeket a digitális kütyüket és applikációkat próbálom kerülni." (Interjúalany 20.)}

Ügyféllel kapcsolatos tényezőként elsősorban az iparági, piaci specifikumokat, illetve az ügyfelek demográfiai jellemzőit említették (KK4). Iparági, piaci specifikumnak kell tekinteni jelen kontextusban az értékesíteni kívánt termékek vagy szolgáltatások minden olyan jellemzőjét, amelyek korlátot jelentenek bármilyen digitalizációra (például megszokásból vagy jogszabályi elöírások miatt elengedhetetlen a személyes kontaktus, vagy épp a papírmentesség elérése). Demográfiai jellemző pedig elsősorban az életkor, a lakhely és a felkészültség.

\section{„... a jogszabályok még mindig sokszor igénylik az írásbeliséget." (Interjúalany 60.)}

\begin{abstract}
„Mivel magas szintű terméket árulunk, ezért inkább csak a támogatásra jellemző a digitalizáció, míg az értékesítésre nem." (Interjúalany 103.)
\end{abstract}

"Jobban bíznak az emberek abban az információban, legalábbis az emberek többsége, ami mondjuk le van írva, írott formában, mintsem, hogy tableten egy grafikont előkeresek." (Interjúalany 6.)

„Attól függetlenül, hogy manapság egyre fontosabbá válik az internet, és ezzel együtt az okostelefonok, laptopok használata, én inkább a hagyományos módszereket alkalmazom." (Interjúalany 32.)

Fontos mindemellett kiemelni, hogy a negatív és semleges vélemények rendszerint maguknak az értékesítési tevékenységeknek a kontextusában jelentek meg, a tág folyamatokat támogató technológiákkal kapcsolatosan nem érzékeltünk explicit szkepszist, ez azonban a technológiával kapcsolatos tudás hiányából is eredhet.

\section{Következtetések és jövőbeni kutatási irányok}

A bemutatott kutatási eredményeinkböl levonható következtetések alapján végsőként javasolt elméleti modellünket a 2. ábrának megfelelően alakítottuk át. Egyrészt azt találtuk, hogy az egyes tevékenységek jelentősebb szerepet képviselnek ebben a kontextusban, másrészt az egyes elemek közötti kapcsolatok kiegészítését is szükségesnek láttuk. Az, hogy az értékesítők milyen mértékben tekinthetők technológiailag felkészültnek, legfeljebb megbecsülni tudjuk, hiszen egy kifejezetten heterogén mintával dolgoztunk. Talán pontosabb azt mondani, hogy látszanak azok a területek, amelyek még fejlesztésre szorulnak, és az a technológiai felkészültség, amelyből fakadóan látszik, hogy az értékesítők munkájuk során milyen technológiákat alkalmaznak, és azokat milyen módon teszik). Kapcsolódva Parasuraman és Colby (2015) megközelítéséhez, a TRI-mérőszám és a ténylegesen alkalmazott technológiák ténylegesen összekapcsolódnak az értékesítői munkakörben dolgozók esetében (KK1). A technológiai felkészültség elöfeltételezi, hogy az ügyfelek kiszolgálása új dimenziókban valósulhat meg, hasonlóan Singh et al. (2019) megoldásaihoz, melyekkel új vevők szerezhetők, vagy régi vevők megtarthatók. Az interjúk során az ügyfelekre kifejtett hatás ugyan csak áttételesen került felszínre, mégis látható egyfajta kölcsönös egymásra hatás az értékesítők és ügyfeleik tekintetében, a technológiai felkészültség dimenziójában (KK2). A rendelkezésre álló technológia jellemzői és azok hatása az elfogadásra vonatkozó attitűdre (mind az észlelt hasznosságon, mind pedig annak használatának észlelt könnyebbségén keresztül) jól körvonalazódtak az interjúkban fellelt válaszok alapján, a következöképpen: a haszonelvü megközelítés, amely az észlelt hasznosság kiemelt szerepét emeli ki, annak közvetlenül a teljesítményre gyakorolt hatása miatt (ld. Ahearne, Hughes \& Schillewaert, 2007), az interjúválaszok alapján sokkal vegyesebb képet mutat, a technológia egyéb jellemzőinek számbavételét is beleértve, túlmutatva Robinson et al. (2005a) kiinduló feltételezéseivel. Az ügyfélkör hatása az attitüdre egyértelmüen látszik abban a tekintetben, ahogy Singh et al. (2019) is kitér erre, hiszen az innovatív vevőkör mintegy „kiköveteli” az újító, előremutató hozzáállást az értékesítőktől, ezáltal várva el minél magasabb szolgál- 
tatásminőséget (KK4). A sok esetben menedzseri szintről kiinduló digitalizációs folyamatok dichotómiája az interjúk esetén csak érintőlegesen jelenik meg (ld. Homburg et al., 2010), azonban az is látható, hogy az értékesítői attitűd áttételesen, a szervezetre történő hatáson keresztül kihat a digitalizációs folyamatok sebességére és eredményére egyaránt (pl. egy közösségimédia-elemekkel integrált CRM-rendszer bevezetésének gördülékenysége függhet a szervezetben dolgozó frontszemélyzet attitűdjétől) (KK5). A digitális átalakulás edukációs megközelítése (ld. Cascio, Mariadoss \& Mouri, 2010) segítségével érthető, hogy az interjúalanyok számára is fontos szempontként jelenhetett meg a digitalizációs infrastruktúra révén elérhető magasabb felkészültségi szint, amelynek révén az értékesítők magasabb tudásszinttel és tudatosabban alkalmazhatják végül innovatív értékesítési rendszereiket és eszközeiket.

A 2. ábrán látható, hogy az ügyfélkör hatása az attitüdre jellemzően áttételesen valósul meg, az interjúk eredményei alapján a tevékenységi kör függvényében. A digitális átalakulás közvetlenül visszahat a technológiai felkészültségre (ezzel megteremtve az átalakuláshoz szükséges infrastruktúrát és hátteret, ld. KK6), és érdekes módon látszik egyfajta visszahatás az ügyfélkör jellegére és összetételére is, amely magyarázható a digitális megoldásokat elönyben részesítő vevők megjelenésével is (ld. még Singh et al., 2019).

Kutatásunkban alapvetően egy értékesítőket és ügyfeleket helyzettől függö mértékben vegyesen tartalmazó ökoszisztémát ábrázolunk, mindamellett részletesen kifejthető, hogy a különféle tényezők az ökoszisztéma másmás szereplőihez köthetők inkább (ld. technológiai felkészültség: értékesítő, attitűd: vegyes, tevékenységi kör: értékesítő, technológiai jellemzők: értékesítő, digitális átalakulás: értékesítő).

Kutatási eredményeink és kutatási kérdéseinkre adott válaszaink a 2. ábrán láthatók. esetlegesen alacsonyabb vásárlóerővel rendelkező szegmens kiszolgálása jelenthet legalább akkora hasznot a vállalatnak, mint a nagy vásárlóerő és alacsony technológiai felkészültségű szegmens kiszolgálása. Másrészt pedig a csatornapolitika kialakítása során is támogathatja a döntéshozatalt a tekintetben, hogy figyelembe veszi az egyes csatornák használatához kapcsolódó szokásokat, kihívásokat és trendeket. Tehát adott esetben felhívhatja a döntéshozók figyelmét olyan csatornák igénybevételére, amelyek jelenleg csak felfutó szakaszban vannak, de később optimálisabbak lehetnek a vállalat számára.

Fontos megemlíteni, hogy a kutatáshoz alkalmazott kvalitatív módszertan nem alkalmas a minta alapján a sokaságra történő általánosításra (ez nem is célja), így eredményei csak a mintavételi kontextus keretében értelmezhetők. A mintajellemzők önmagukban korlátot képeznek, hiszen a mintaalanyok válaszai saját szubjektív észleléseiket reprezentálják, így pl. technológiai felkészültségüket torzítva becsülhetik meg, valamint technológiai felkészültségük korlátjaiból fakadóan a digitális átalakulásról alkotott vélekedéseik is alul- vagy felülbecsülhetik az értékesítő szervezet tényleges - digitalizáció szempontjából értelmezhető - állapotát. Az egyes tevékenységek és a digitális megoldások által megoldható és jelenleg megoldás alatt lévő kihívások további pontosítása szükséges.

Jelen kutatás terjedelmi korlátai nem tették lehetővé, hogy a téma fontosabb aspektusait teljes mélységükben vizsgáljuk, így jövőbeni kutatási irányok kijelölése szükséges. Egyrészt fontosnak tartjuk a jelenleg felállított konceptuális modell kvantitatív tesztelését, másrészt az esetlegesen felmerülő további moderáló tényezők azonosítását (így az értékesítés kétoldalú jellegének, ügyféloldali sajátosságainak vizsgálata kifejezetten fontos), illetve a modell jelenleg feltárt elemeinek mélyebb megismerését és bemutatását.

\section{Az értékesítés digitális transzformációját befolyásoló tényezők végső elméleti modellje}

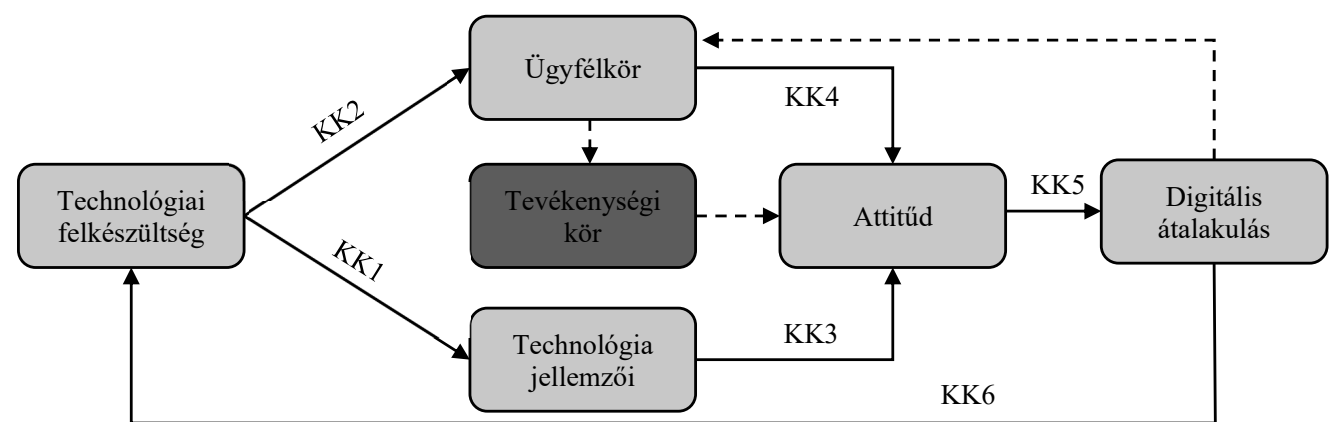

Megjegyzés: Sötétebb színnel, illetve szaggatott vonallal jelöltük az interjúk feldolgozása után feltárt elemeket és kapcsolatokat.

Forrás: saját szerkesztés

Kutatásunk menedzseri implikációi a következőképpen foglalhatók össze. Egyrészt a felvázolt gondolatmenet támogathatja a szegmentálást azáltal, hogy az egyes csoportok értéke mellett azok technológiai felkészültsége is bekerül a szempontok közé. Ez a gyakorlatban azt jelenti, hogy egy magasabb technológiai felkészültséggel, de
Emellett a nemzetközi kontextus is megfontolandó lehet a téma kutatását illetően (Malota, 2011). Végül, de nem utolsósorban további kutatásra adhat lehetőséget azon elméleti források jelen kontextusban történő részletesebb vizsgálata, amelyeket jelen tanulmányban alapozó jelleggel érintettünk (Davis, 1986; Parasuraman, 2000). 


\section{Felhasznált irodalom}

Ahearne, M., Hughes, D. E., \& Schillewaert, N. (2007). Why sales reps should welcome information technology: Measuring the impact of CRM-based IT on sales effectiveness. International Journal of Research in Marketing, 24(4), 336-349.

https://doi.org/10.1016/j.ijresmar.2007.09.003

Ahearne, M., Lam, S. K., Mathieu, J. E., \& Bolander, W. (2010). Why are some salespeople better at adapting to organizational change? Journal of Marketing, 74(3), 65-79.

https://doi.org/10.1509/jmkg.74.3.65

Ajzen, I., \& Fishbein, M. (1980). Understanding attitudes and predicting social behaviour. Englewood Cliffs New Jersey: Prentice-Hall.

Avlonitis, G. J., \& Panagopoulos, N. G. (2005). Antecedents and consequences of CRM technology acceptance in the sales force. Industrial Marketing Management, 34(4), 355-368.

https://doi.org/10.1016/j.indmarman.2004.09.021

Bauer, A., Mitev, A. Z., \& Gáti, M. (2019). Kommunikációs csatornák és az innovációs magatartás hatása a bizalomra, valamint a vevőkapcsolati teljesítményre a személyes értékesítésben. Vezetéstudomány, 50(9), 6-13. https://doi.org/10.14267/VEZTUD.2019.09.02

Bencsik, A. (2021). Vezetői felkészültség felmérése a digitális kor kihívásaira. Nemzetközi összehasonlítás. Vezetéstudomány, 52(4), 93-108.

https://doi.org/10.14267/VEZTUD.2021.04.08

Buehrer, R. E., Senecal, S., \& Bolman Pullins, E. (2005). Sales force technology usage - Reasons, barriers, and support: An exploratory investigation. Industrial Marketing Management, 34(4), 389-398.

https://doi.org/10.1016/j.indmarman.2004.09.017

Bush, A. J., Bush, V. D., Orr, L. M., \& Rocco, R. A. (2007). Sales technology: Help or hindrance to ethical behaviors and productivity? Journal of Business Research, 60(11), 1198-1205.

https://doi.org/10.1016/j.jbusres.2007.04.007

Bush, A. J., Moore, J. B., \& Rocco, R. (2005). Understanding sales force automation outcomes: A managerial perspective. Industrial Marketing Management, 34(4), 369-377.

https://doi.org/10.1016/j.indmarman.2004.09.016

Cascio, R., Mariadoss, B. J., \& Mouri, N. (2010). The impact of management commitment alignment on salespersons' adoption of sales force automation technologies: An empirical investigation. Industrial Marketing Management, 39(7), 1088-1096.

https://doi.org/10.1016/j.indmarman.2009.12.010

Chaffey, D., \& Smith, P. (2013). Emarketing Excellence. London: Routledge.

https://doi.org/10.4324/9780203082812

Davis, F D. (1985). A technology acceptance model for empirically testing new end-user information systems: Theory and results (Doctoral dissertation). Massachusetts Institute of Technology, Cambridge, Mass. https://doi.org/oclc/56932490
Davis, Fred D. (1989). Perceived Usefulness, Perceived Ease of Use, and User Acceptance of Information Technology. MIS Quarterly, 13(3), 319-340. https://doi.org/10.2307/249008

Gohmann, S. F., Guan, J., Barker, R. M., \& Faulds, D. J. (2005). Perceptions of sales force automation: Differences between sales force and management. Industrial Marketing Management, 34(4), 337-343. https://doi.org/10.1016/j.indmarman.2004.09.014

Gubán, Á., \& Sándor, Á. (2021). A KKV-k digitálisérettség-mérésének lehetőségei. Vezetéstudomány, 52(3), 13-28. https://doi.org/10.14267/VEZTUD.2021.03.02

Homburg, C., Wieseke, J., \& Kuehnl, C. (2010). Social influence on salespeople's adoption of sales technology: A multilevel analysis. Journal of the Academy of Marketing Science, 38(2), 159-168. https://doi.org/10.1007/s11747-009-0157-x

Kvale, S. (2008). Doing Interviews. Thousand Oaks: Sage Publications. https://books.google.hu/books?id=x71Xd08rD7IC

Kvale, S. (1994). InterViews: An introduction to qualitative research interviewing. Thousand Oaks: Sage Publications, Inc.

Malota, E. (2011). Kultúrák és kommunikáció. Esettanulmányok és gyakorlatok. Budapest: Budapesti Corvinus Egyetem.

Moore, G. A. (1999). Crossing the Chasm: Marketing and Selling High-Tech Products to Mainstream Customers. New York: HarperBusiness. https://doi.org/10.1017/CBO9781107415324.004

Morgan, A. J., \& Inks, S. A. (2001). Technology and the Sales Force: Increasing Acceptance of Sales Force Automation. Industrial Marketing Management, 30(5), 463-472., https://doi.org/10.1016/S0019-8501(99)00115-7

Obal, M., \& Morgan, T. (2018). Investigating the Moderating Effects of Perceived Technological Change on Sales Force Acceptance. Journal of Business-to-Business Marketing, 25(4), 319-338., https://doi.org/10.1080/1051712X.2018.1519971

Parasuraman, A. (2000). Technology Readiness Index (TRI). A Multiple-Item Scale to Measure Readiness to Embrace New Technologies. Journal of Service Research, 2(4), 307-320., https://doi.org/10.1177/109467050024001

Parasuraman, A., \& Colby, C. L. (2015). An Updated and Streamlined Technology Readiness Index: TRI 2.0. Journal of Service Research, 18(1), 59-74., https://doi.org/10.1177/1094670514539730

Park, J. E., Kim, J., Dubinsky, A. J., \& Lee, H. (2010). How does sales force automation influence relationship quality and performance? The mediating roles of learning and selling behaviors. Industrial Marketing Management, 39(7), 1128-1138. https://doi.org/10.1016/j.indmarman.2009.11.003

Rangarajan, D., Jones, E., \& Chin, W. (2005). Impact of sales force automation on technology-related stress, effort, and technology usage among salespeople. Industrial Marketing Management, 34(4), 345-354. https://doi.org/10.1016/j.indmarman.2004.09.015 
Robinson, L., Marshall, G. W., \& Stamps, M. B. (2005a). An empirical investigation of technology acceptance in a field sales force setting. Industrial Marketing Management, 34(4), 407-415. https://doi.org/10.1016/j.indmarman.2004.09.019

Robinson, L., Marshall, G. W., \& Stamps, M. B. (2005b). Sales force use of technology: Antecedents to technology acceptance. Journal of Business Research, 58(12), 1623-1631. https://doi.org/10.1016/j.jbusres.2004.07.010

Rodriguez, M., \& Boyer, S. (2020). The impact of mobile customer relationship management (mCRM) on sales collaboration and sales performance. Journal of Marketing Analytics, 8(3), 137-148. https://doi.org/10.1057/s41270-020-00087-3

Rogers, E. M. (1995). Diffusion of Innovations. New York: Free Press. https://books.google.hu/books?id=LpkPAQAAMAAJ

Schillewaert, N., Ahearne, M. J., Frambach, R. T., \& Moenaert, R. K. (2005). The adoption of information technology in the sales force. Industrial Marketing Management, 34(4), 323-336. https://doi.org/10.1016/j.indmarman.2004.09.013

Sharma, A., \& Sheth, J. (2010). A framework of technology mediation in consumer selling: Implications for firms and sales management. Journal of Personal Selling and Sales Management, 30(2), 121-129. https://doi.org/10.2753/PSS0885-3134300203

Singh, J., Flaherty, K., Sohi, R. S., Deeter-Schmelz, D., Habel, J., Le Meunier-FitzHugh, K., Malshe, A., Mullins, R., \& Onyemah, V. (2019). Sales profession and professionals in the age of digitization and artificial intelligence technologies: concepts, priorities, and questions. Journal of Personal Selling and Sales Management, 39(1), 2-22.

https://doi.org/10.1080/08853134.2018.1557525

Singh, S. K., Marinova, D., \& Singh, J. (2020). Business-to-Business E-Negotiations and Influence Tactics. Journal of Marketing, 84(2), 47-68. https://doi.org/10.1177/0022242919899381

Speier, C., \& Venkatesh, V. (2002). The hidden minefields in the adoption of sales force automation technologies. Journal of Marketing, 66(3), 98-111. https://doi.org/10.1509/jmkg.66.3.98.18510
Syam, N., \& Sharma, A. (2018). Waiting for a sales renaissance in the fourth industrial revolution: Machine learning and artificial intelligence in sales research and practice. Industrial Marketing Management, 69, 135-146. https://doi.org/10.1016/j.indmarman.2017.12.019

Taiminen, H. M., \& Karjaluoto, H. (2015). The usage of digital marketing channels in SMEs. Journal of Small Business and Enterprise Development, 22(4), 633-651. https://doi.org/10.1108/JSBED-05-2013-0073

Turner, D. W. (2010). Qualitative interview design: A practical guide for novice investigators. Qualitative Report, 15(3), $754-760$. https://doi.org/10.46743/2160-3715/2010.1178

Venkatesh, V., \& Bala, H. (2008). Technology Acceptance Model 3 and a Research Agenda on Interventions. Decision Sciences - DECISION SCI, 39(2), $273-315$. https://doi.org/10.1111/j.1540-5915.2008.00192.x

Venkatesh, V., \& Davis, F. D. (2000). A Theoretical Extension of the Technology Acceptance Model: Four Longitudinal Field Studies. Management Science, 46(2), 186-204. http://www.jstor.org/stable/2634758

Venkatesh, V., Morris, M., Davis, G., \& Davis, F. (2003). User Acceptance of Information Technology: Toward a Unified View. MIS Quarterly, 27(3), 425-478. https://doi.org/10.2307/30036540

Vial, G. (2019). Understanding digital transformation: A review and a research agenda. Journal of Strategic Information Systems, 28(2), 118-144. https://doi.org/10.1016/j.jsis.2019.01.003

Williams, M., \& Moser, T. (2019). The Art of Coding and Thematic Exploration in Qualitative Research. International Management Review, 15(1), 45-55. http:// www.imrjournal.org/uploads/1/4/2/8/14286482/imrv15n1art4.pdf

World Economic Forum (2019). The Cybersecurity Guide for Leaders in Today's Digital World. http://www3. weforum.org/docs/WEF_Cybersecurity_Guide_for_ Leaders.pdf

World Economic Forum (2020). Jobs of Tomorrow-Mapping Opportunity in the New Economy. http://www3. weforum.org/docs/WEF_Jobs_of_Tomorrow_2020. pdf 